\title{
A STUDY ON PHYTOCHEMICAL ANALYSIS AND ANTIBACTERIAL ACTIVITY OF QUERCUS MACRANTHERA SUBSP. SYSPIRENSIS (K. KOCH) MENITSKY BRANCH AND LEAF EXTRACTS
}

\author{
QUERCUS MACRANTHERA SUBSP. SYSPIRENSIS (K. KOCH) MENITSKY'IN DAL VE \\ YAPRAK EKSTRELERININ FITOKIMYASAL ANALIZİ VE ANTIBAAKTERIYYEL AKTIVITESI \\ ÜZERINE BIR ÇALIŞMA
}

\section{Merve Eylul KIYMACI ${ }^{1 *} \mathbb{D}$, Kenan Can TOK ${ }^{2} \mathbb{D}$, Muhammed Mesud HÜRKUL ${ }^{3}$}

${ }^{1}$ University of Health Sciences Turkey, Gülhane Faculty of Pharmacy, Department of Pharmaceutical Microbiology, Ankara, Turkey

${ }^{2}$ Ankara University, Institute of Forensic Sciences, Department of Forensic Toxicology, Ankara, Turkey

${ }^{3}$ Ankara University, Faculty of Pharmacy, Department of Pharmaceutical Botany, Ankara, Turkey

\section{ABSTRACT}

Objective: Oak species are medicinal plants with traditional use around the world. These species, which are very rich in tannins, have potential as antibacterial agents in terms of the polyphenolic compounds content. In this study, the antibacterial potential and phytochemical content of the branches and leaves of Quercus macranthera subsp. syspirensis, which is endemic to Turkey, were investigated.

Material and Method: Plant materials were collected from Araç (Kastamonu/Turkey) in 2020. Methanol extracts were prepared from dried and powdered branches and leaves. The antibacterial activity test was evaluated by broth microdilution method as a minimal inhibition concentration (MIC) against Staphylococcus aureus ATCC 29213, Staphylococcus epidermidis ATCC 35984, Enterococcus faecalis ATCC 29212, Klebsiella pneumoniae ATCC 13883, Pseudomonas aeruginosa ATCC 27853, Escherichia coli ATCC 25922, Acinetobacter baumannii ATCC 19606 and Bacillus subtilis ATCC 6633. The GC-MS analysis of extracts were performed using an Agilent 6890 gas chromatograph equipped with an Agilent $5973 \mathrm{~N}$ quadrupole mass spectrometer (Agilent, USA). The compounds were identified by comparing the mass spectrum ratio of the sample with the data available in NIST 2014 Mass Spectral Library.

\footnotetext{
* Corresponding Author/Sorumlu Yazar: Merve Eylul Kiymaci e-mail / e-posta: mekiymaci@ gmail.com, Phone / Tel.: +90 3123046073
} 
Result and Discussion: As a result, it was found that the branch extracts were more effective than the leaf extracts and both branch and leaf extracts showed the highest activity against Bacillus subtilis ATCC 6633 strain $(48.8 \mu \mathrm{g} / \mathrm{ml}, 97.6 \mu \mathrm{g} / \mathrm{ml}$, respectively). The extracts also showed antibacterial activity at varying concentrations on other test strains.

Keywords: Antibacterial, branch, GC-MS, leaf, Quercus macranthera subsp. syspirensis

\section{$\ddot{\mathbf{O Z Z}}$}

Amaç: Meşe türleri dünya genelinde geleneksel kullanımı olan tıbbi bitkilerdendir. Tanen bakımından oldukça zengin olan bu türlerin içerdikleri polifenolik bileşikler açısından antibakteriyel ajan olarak potansiyelleri vardır. Bu çalışmada Türkiye için endemik olan Quercus macranthera subsp. syspirensis'in dal ve yapraklarının antibakteriyel potansiyeli ve fitokimyasal içeriği araştırılmışstır.

Gereç ve Yöntem: Bitki materyalleri 2020 yllında Araç'tan (Kastamonu/Türkiye) toplanmıştır. Kurutulmuş ve toz haline getirilmiş dal ve yapraklardan metanol ekstreleri hazırlanmıştır. Antibakteriyel aktivite, minimum inhibisyon konsantrasyonu (MIC) olarak sivl mikrodilüsyon yöntemiyle, Staphylococcus aureus ATCC 29213, Staphylococcus epidermidis ATCC 35984, Enterococcus faecalis ATCC 29212, Klebsiella pneumoniae ATCC 13883, Pseudomonas aeruginosa ATCC 27853, Escherichia coli ATCC 25922, Acinetobacter baumannii ATCC 19606 ve Bacillus subtilis ATCC 6633 mikroorganizmaları üzerine test edilmiştir. Ekstrelerin GC-MS analizi, Agilent 5973 N dört kutuplu kütle spektrometresi (Agilent, ABD) ile donatılmış bir Agilent 6890 gaz kromatografi kullanılarak yapllmıştır. Bileşikler, numunenin kütle spektrum oranı NIST 2014 Kütle Spektral Kütüphanesinde bulunan verilerle karşılaş̧tırılarak tanımlanmuştır.

Sonuç ve Tartışma: Sonuç olarak, dal ekstrelerinin yaprak ekstrelerinden daha etkili olduğu bulundu ve her iki ekstrenin de en yüksek antibakteriyel aktiviteyi Bacillus subtilis ATCC 6633 suş̧na karşı gösterdiği belirlendi. Ekstreler ayrıca diğer test suşları üzerinde değişen konsantrasyonlarda aktivite gösterdi.

Anahtar kelimeler: Antibakteriyel, GC-MS, dal, yaprak, Quercus macranthera subsp. syspirensis

\section{INTRODUCTION}

In the search for a solution to antimicrobial resistance that has emerged in recent years, active substances obtained from plants come to the fore. Although $25-50 \%$ of existing pharmaceuticals are obtained from herbal raw materials. Plants contain various secondary metabolites with antimicrobial activity such as tannins, terpenoids, alkaloids and flavonoids that are one of the go-to reservoirs to alleviate this problem [1].

The distribution areas of the genus Quercus L. are in the Northern Hemisphere and these plants, called oaks, have 461 accepted species worldwide [2,3]. Oak species are rich in tannins, they are also known to contain gallic acid, caffeic acid, ferulic acid, ellagic acid, (-)-epicatechin, (-)-epigallocatechin, $(+)$-catechin and (+)-gallocatechin [4-10]. It is widely used as traditionally in the treatment of diabetes, wounds, respiratory diseases, diarrhea, obesity, fungus, ulcers, toothache, hemorrhoids, abscesses, dermatitis and burns [11-24]. It has been proven that the medically important Quercus species have antibacterial, anticancer, gastroprotective, antiviral, cardioprotective and hepatoprotective activities [2534]. Quercus macranthera subsp. syspirensis (K. Koch) Menitsky is endemic to Turkey, also called "ispir meşesi", the plant is a small deciduous tree, the leaves are obovate with 6-10 primary veins and the stipules are filiform [35-36]. 
In this study, the antibacterial activity of the branch (BM) and leaf (LM) methanol extracts of $Q$. macranthera subsp. syspirensis were investigated and the phytochemical analysis of the extracts were carried out with Gas Chromatography-Mass Spectrometry (GC-MS).

\section{MATERIAL AND METHOD}

\section{Plant materials and preparation of extracts}

Plant materials were collected from Araç (Kastamonu/Turkey) in 2020. A voucher specimen was deposited in the Ankara University Faculty of Pharmacy Herbarium (AEF). The collected plant parts (branches and leaves) were dried in the shade. The plant parts were extracted by using the maceration method with methanol.

\section{Antibacterial activity}

Antibacterial activity of the branch and leaf extracts of $Q$. macranthera subsp. syspirensis was tested against Staphylococcus aureus ATCC 29213, Staphylococcus epidermidis ATCC 35984, Enterococcus faecalis ATCC 29212, Klebsiella pneumoniae ATCC 13883, Pseudomonas aeruginosa ATCC 27853, Escherichia coli ATCC 25922, Acinetobacter baumannii ATCC 19606 and Bacillus subtilis ATCC 6633. Antibacterial activity test was evaluated by broth microdilution method as a minimal inhibition concentration (MIC) according to European Committee on Antimicrobial Susceptibility Testing standarts [37].

\section{GC/MS analysis}

For GC-MS analysis of plant extracts, a two-step derivatization method including methoximation (methoxyamine derivatization) and silylation was used [38]. Methoxyamine reacts with the carbonyl groups of sugars to form oxime derivatives, thus preventing ring formation that causes multiple chromatographic peaks [39]. It also helps to protect $\alpha$-keto acids from decarboxylation. Before the methoxyamine derivatization, methoxyamine hydrochloride (MeOX) (Germany, Sigma-Aldrich) solution freshly prepared in pyridine $(25 \mathrm{mg} / \mathrm{ml}) .30 \mu \mathrm{MeOX}$ solution added to the dried extracts and waited $90 \mathrm{~min}$ at $30{ }^{\circ} \mathrm{C}$ for oximation of sugars. In the second step of derivatization, silylation was performed using $30 \mu 1$ of BSTFA-1\%TMCS (Germany, Sigma-Aldrich).

The analysis was performed using an Agilent 6890 gas chromatograph equipped with an Agilent 5973N quadrupole mass spectrometer detector (Santa Clara, USA). All samples were analyzed using the RTX-5MS Low-Bleed fused silica gas chromatography capillary column $(30 \mathrm{~m} \times 0.25 \mathrm{~mm}$ i.d. $\times$ $0.25 \mu \mathrm{m}$ film thickness) (Restek, USA). Ultrapure helium was preferred as the carrier gas and a constant flow rate of $1.5 \mathrm{ml} / \mathrm{min}$ was used. The injection port was maintained at $280{ }^{\circ} \mathrm{C}$. The ion source, quadrupole and transfer line temperatures were adjusted at $230{ }^{\circ} \mathrm{C}, 150{ }^{\circ} \mathrm{C}$ and $280{ }^{\circ} \mathrm{C}$, respectively. The GC oven program was held at $50{ }^{\circ} \mathrm{C}$ for $2 \mathrm{~min}$, and then increased to $280{ }^{\circ} \mathrm{C}$ at $4{ }^{\circ} \mathrm{C} / \mathrm{min}$ and held 
for $10 \mathrm{~min}$. Total analysis time was $70 \mathrm{~min}$. The mass range was $40-550 \mathrm{~m} / \mathrm{z}$ and the scan rate was 0.45 scan per second in full scan mode. Electron ionization was carried out using $70 \mathrm{eV}$ ionization energy. Compounds were identified using MS Search software and the NIST 2014 Mass Spectral Library.

\section{RESULT AND DISCUSSION}

The MIC results of tested extracts were shown in Table 1. It was determined that the branch extracts (BM) were more effective than the leaf extracts (LM) and both extracts showed the highest antibacterial activity against Bacillus subtilis ATCC 6633 strain. The extracts also showed activity at varying concentrations on other test strains.

Table 1. Antibacterial activity results for tested extracts as MIC.

\begin{tabular}{|c|c|c|c|c|c|c|c|c|}
\hline \multirow{2}{*}{ Extracts } & \multicolumn{8}{|c|}{ Minimal inhibition concentrations $(\mu \mathrm{m} / \mathrm{ml})$} \\
\cline { 2 - 9 } & $\begin{array}{c}\text { S. aureus } \\
\text { ATCC 29213 }\end{array}$ & $\begin{array}{c}\text { S. epidermidis } \\
\text { ATCC 35984 }\end{array}$ & $\begin{array}{c}\text { E. faecalis } \\
\text { ATCC 29212 }\end{array}$ & $\begin{array}{c}\text { E. coli } \\
\text { ATCC 25922 }\end{array}$ & $\begin{array}{c}\text { P. aeruginosa } \\
\text { ATCC 27853 }\end{array}$ & $\begin{array}{c}\text { A. baumannii } \\
\text { ATCC 19606 }\end{array}$ & $\begin{array}{c}\text { K. pneumoniae } \\
\text { ATCC 13883 }\end{array}$ & $\begin{array}{c}\text { B. subtilis } \\
\text { ATCC 6633 }\end{array}$ \\
\hline BM & 781.25 & 1562.5 & 6250 & 3125 & 1562 & 781.25 & 781.25 & 48.8 \\
\hline LM & 3125 & 1562.5 & 6250 & 6250 & 6250 & 781.25 & 781.25 & 97.6 \\
\hline \multicolumn{78}{|c|}{ MIC results of E.coli for ciprofloxacin was found $0.078 \mu \mathrm{g} / \mathrm{ml}}$. \\
\hline
\end{tabular}

Since Q. macranthera subsp. sypirensis is an endemic plant, there is no literature data other than a study conducted in 2007 reported [40] that Q. macranthera subsp. sypirensis extracts prepared with different solvents (petroleum ether, ethyl acetate, $n$-butanol fractions and lyophilized water phase of methanol extract) showed the antibacterial activity at different concentrations (512- $\geq 1024 \mu 1)$ against Escherichia coli ATCC 25922, Staphylococcus aureus ATCC 29213, Enterococcus faecalis ATCC 29212 and Pseudomonas aeruginosa ATCC 27853. Therefore, the current study is important in terms of bringing data to the literature. Previous studies have shown that different Quercus species have antibacterial activity against various Gram positive and Gram negative bacteria. Ahmed et al. (2021) [41] determined that Quercus floribunda Lindl. ex A. Camus acorn extract showed antibacterial activity against B. subtilis, E. coli, K. pneumonie and S. aureus. Aleebrahim-Dehkordy et al. (2019) [42] showed that Quercus brantii Lindl. acorn ethanol (70\%) extracts had inhibitory activity against $S$. aureus and $E$. faecalis. In the study of Elansary et al. (2019) [43], the antibacterial activities of the bark methanolic extracts of three Quercus species (Q. robur, Q. macrocarpa and Q. acutissima) exhibited antibacterial activities against most species of microorganism studied. The highest antibacterial activities were found against S. aureus ATCC 6538 (MIC $0.23 \mathrm{mg} / \mathrm{ml}$ ), P. aeruginosa ATCC 27853 (MIC $0.05 \mathrm{mg} / \mathrm{ml}$ ), Bacillus cereus ATCC 14579 (MIC $0.11 \mathrm{mg} / \mathrm{ml}$ ), Listeria monocytogenes (clinical isolate) (MIC 0.25 $\mathrm{mg} / \mathrm{ml}$ ), E. coli ATCC 35210 (MIC $0.10 \mathrm{mg} / \mathrm{ml}$ ) for the extracts of Q. robur, compared to streptomycin. The methanol extracts of Quercus alba L. barks were tested for growth inhibition of S. aureus $\left(\mathrm{IC}_{50} 64\right.$ $\mu \mathrm{g} / \mathrm{ml})$, K. pneumoniae $\left(\mathrm{IC}_{50} 32 \mu \mathrm{g} / \mathrm{ml}\right.$ ), and A. baumannii $\left(\mathrm{IC}_{50} 32 \mu \mathrm{g} / \mathrm{ml}\right)$, and evaluated for biofilm 
inhibition ( $\mathrm{IC}_{50} 1 \mu \mathrm{g} / \mathrm{ml}$ ) against $S$. aureus by Dettweiler et al. (2019) [44]. Sánchez-Burgosa et al. (2013) [45] investigated the antibacterial activity of leaf aqueous extracts of $Q$. resinosa against $E$. coli ATCC 35218 (MIC $1.895 \mathrm{mg} / \mathrm{ml}$ ), S. epidermidis ATCC 12228 (MIC $0.348 \mathrm{mg} / \mathrm{ml}$ ), K. pneumoniae ATCC 13883 (MIC $0.547 \mathrm{mg} / \mathrm{ml}$ ), P. mirabilis ATCC 12453 (MIC $0.708 \mathrm{mg} / \mathrm{ml}$ ) and P. vulgaris ATCC 49132 (MIC $0.265 \mathrm{mg} / \mathrm{ml}$ ).

Figure 1 and Figure 2 show the major compounds identified in branch and leaf extract by GCMS. The analyzes show the presence of 17 and 19 compounds (Table 2-3), respectively in branch and leaf samples. Q. macranthera subsp. sypirensis branch extract contains 1,49\% Carbonitrile, 1,50\% Flavanoid, 1,63\% Terpenoid, 2.28\% Acid, 2.3\% Carboxylic Acid, 2.58\% Sugar Alcohol, 2.95\% Steroids, 5.9\% Cylopentapyrazoles, 5.94\% Sulfonamide, 22.95\% Phenols, 50,48\% Sugars. However, Q. macranthera subsp. sypirensis leaf contains $0.59 \%$ Carbonitrile, $1.45 \%$ Steroids, $2.07 \%$ Sulfonamide, 2.32\% Cylopentapyrazoles, 2.58\% Sugar Alcohol, 5.41\% Acids, 23.95\% Phenols, 24,81\% Carboxylic Acids, 36.82\% Sugars.

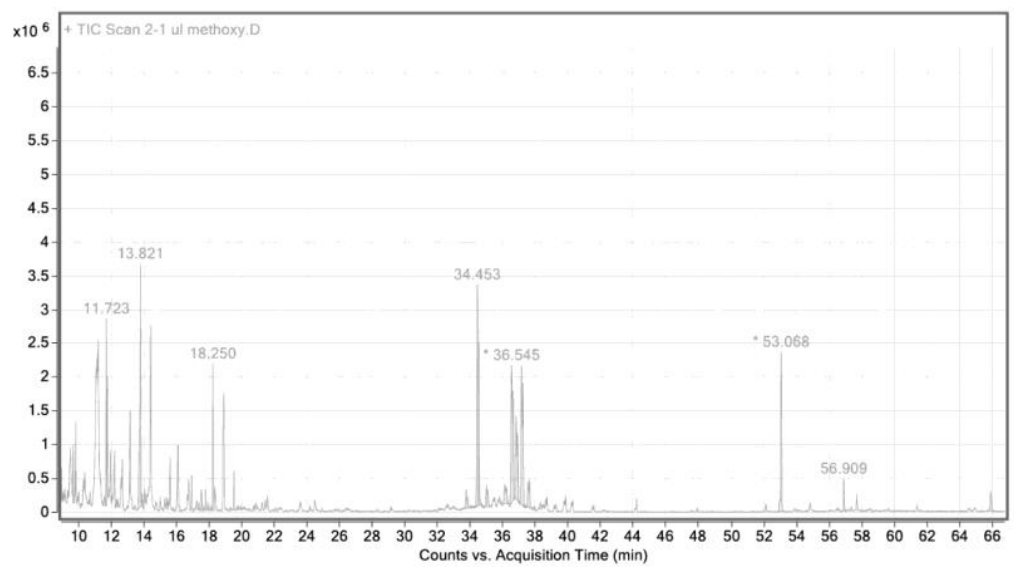

Figure 1. Compounds identified by GC-MS in Q. macranthera subsp. sypirensis branch extract.

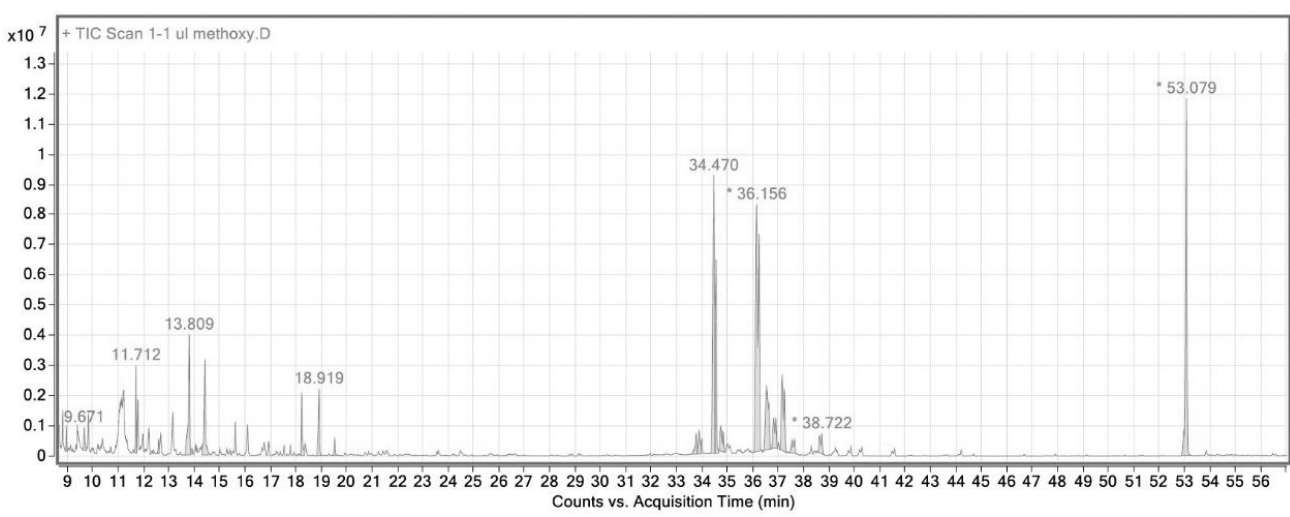

Figure 2. Compounds identified by GC-MS in Q. macranthera subsp. sypirensis leaf extract. 
Table 2. Compounds identified by GC-MS in Q. macranthera subsp. sypirensis branch extract.

\begin{tabular}{|c|c|c|c|c|}
\hline$\#$ & $\begin{array}{c}\text { RT } \\
\text { (min) }\end{array}$ & Identified compounds & $\%$ & Classification \\
\hline 1 & 9.671 & Boric acid & 2.28 & Acid \\
\hline 2 & 11.712 & N-(2-Hydroxy-1-phenylethyl)-benzenesulfonamide & 5.95 & Sulfonamide \\
\hline 3 & 18.233 & Benzo[c][1,2,5]-thiadiazole, $4,5,6,7-t e t r a m e t h y l-$ & 5.90 & Cylopentapyrazoles \\
\hline 4 & 18.919 & Glycerol & 2.58 & Sugar alcohol \\
\hline 5 & 19.536 & 3-Amino-2,6,6,7-tetramethyl-1-thioxo-1,2,5,6,7,8-hexahydro- & 1.49 & Cabonitrile \\
\hline 6 & 33.778 & [2,7]naphthyridine-4-carbonitrile & Steroid \\
\hline 7 & 34.453 & Androst-5,7-dien-3-ol-17-one, acetate & 1.37 & Phenol \\
\hline 8 & 34.550 & Myo-Inositol & 15.6 & Phenol \\
\hline 9 & 35.002 & Scyllo-Inositol & 7.35 & Steroid \\
\hline 10 & 36.156 & Quininic acid & 1.58 & Sugar \\
\hline 11 & 36.545 & D-(-)-Fructose & 2.30 & Carboxylic acid \\
\hline 12 & 36.825 & D-(-)-Fructose & 14.1 & Sugar \\
\hline 13 & 37.162 & D-(+)-Talose & 8.64 & Sugar \\
\hline 14 & 37.648 & D-Allose & 15.4 & Sugar \\
\hline 15 & 53.079 & Sucrose & 3.02 & Sugar \\
\hline 16 & 56.908 & Catechine & 1.50 & Flavanoid \\
\hline 17 & 65.904 & Lupeol & 1.63 & Terpenoid \\
\hline
\end{tabular}

Table 3. Compounds identified by GC-MS in Q. macranthera subsp. sypirensis leaf extract.

\begin{tabular}{|c|c|c|c|c|}
\hline$\#$ & $\begin{array}{c}\text { RT } \\
\text { (min) }\end{array}$ & Identified compounds & $\%$ & Classification \\
\hline 1 & 9.671 & Boric acid & 0.76 & Acid \\
\hline 2 & 11.712 & N-(2-Hydroxy-1-phenylethyl)-benzenesulfonamide & 2.07 & Sulfonamide \\
\hline 3 & 12.603 & Methylphosphonic acid & 0.45 & Acid \\
\hline 4 & 14.421 & Benzohydroxamic acid & 4.20 & Acid \\
\hline 5 & 18.233 & Benzo[c][1,2,5]-thiadiazole, $4,5,6,7-t e t r a m e t h y l-$ & 2.32 & Cylopentapyrazoles \\
\hline 6 & 18.919 & Glycerol & 2.58 & Sugar alcohol \\
\hline 7 & 19.536 & 3-Amino-2,6,6,7-tetramethyl-1-thioxo-1,2,5,6,7,8-hexahydro- & 0.59 & Cabonitrile \\
\hline 8 & 33.778 & [2,7]naphthyridine-4-carbonitrile & 1.13 & Sugar \\
\hline 9 & 33.887 & B-D-Glucopyranosiduronic acid & 1.45 & Steroid \\
\hline 10 & 34.470 & Pregnane-3,17,20,21-tetrol, $(3 \alpha, 5 \beta, 17 \alpha, 20 \alpha)-$ & 16.3 & Phenol \\
\hline 11 & 34.550 & Myo-Inositol & 7.65 & Phenol \\
\hline 12 & 34.750 & Scyllo-Inositol & 2.01 & Carboxylic acid \\
\hline 13 & 36.156 & Shikimic acid & 22.8 & Carboxylic acid \\
\hline 14 & 36.545 & Quininic acid & 6.51 & Sugar \\
\hline 15 & 36.825 & D-(-)-Fructose & 2.73 & Sugar \\
\hline 16 & 37.162 & D-(-)-Fructose & 6.50 & Sugar \\
\hline 17 & 37.648 & D-(+)-Talose & 1.22 & Sugar \\
\hline 18 & 38.722 & D-Allose & 1.63 & Sugar \\
\hline 19 & 53.079 & D-Allofuranose & 17.1 & Sugar \\
\hline
\end{tabular}

\section{AUTHOR CONTRIBUTIONS}

Conception: M.E.K., K.C.T., M.M.H.; Design: M.E.K., K.C.T., M.M.H.; Supervision: M.E.K., K.C.T., M.M.H.; Resources: M.E.K., K.C.T., M.M.H.; Materials: M.E.K., K.C.T., M.M.H.; Data collection and/or processing: M.E.K., K.C.T., M.M.H.; Analysis and/or interpretation: M.E.K., K.C.T., M.M.H.; Literature search: M.E.K., K.C.T., M.M.H.; Writing manuscript: M.E.K.; Critical review: M.E.K., K.C.T., M.M.H.; Other: - 


\section{CONFLICT OF INTEREST}

The authors declare no conflict of interest.

\section{ETHICS COMMITTEE APPROVAL}

The authors declare that the ethics committee approval is not required for this study.

\section{REFERENCES}

1. Mahizan, N. A., Yang, S. K., Moo, C. L., Song, A. A., Chong, C. M., Chong, C. W., Abushelaibi, A., Lim, S. E., Lai, K. S. (2019). Terpene Derivatives as a Potential Agent against Antimicrobial Resistance (AMR) Pathogens. Molecules, 24(14), 2631. [CrossRef]

2. Morales, D. (2021). Oak trees (Quercus spp.) as a source of extracts with biological activities: A narrative review. Trends in Food Science \& Technology, 109, 116-125. [CrossRef]

3. POWO. (2021). Plants of the World Online. Facilitated by the Royal Botanic Gardens, Kew. http://www.plantsoftheworldonline.org Accessed: 21.11.2021.

4. Buche, G., Colas, C., Fougère, L., Giordanengo, T., Destandau, E. (2020). Untargeted UHPLCQ- TOF- HRMS based determination of discrimating compounds for oak species Quercus robur L. and Quercus petraea Liebl. identification. Phytochemical Analysis, 32(5), 660-671. [CrossRef]

5. Evans, W. (2002). Trease and Evans pharmacognosy (15th ed.). WB Saunders.

6. Marinov, M. G., Dimitrova, E. D., Puech, J. L. (1997). Kinetics of ellagitannin extraction from oak wood using white wine. Journal of Wine Research, 8(1), 29-40. [CrossRef]

7. Perez, A. J., Pecio, Ł., Kowalczyk, M., Kontek, R., Gajek, G., Stopinsek, L., Mirt, I., Oleszek, W., Stochmal, A. (2017). Triterpenoid components from oak heartwood (Quercus robur) and their potential health benefits. Journal of Agricultural and Food Chemistry, 65(23), 4611-4623. [CrossRef]

8. Ricci, A., Parpinello, G. P., Palma, A. S., Teslić, N., Brilli, C., Pizzi, A., Versari, A. (2017). Analytical profiling of food-grade extracts from grape (Vitis vinifera sp.) seeds and skins, green tea (Camellia sinensis) leaves and Limousin oak (Quercus robur) heartwood using MALDI-TOFMS, ICP-MS and spectrophotometric methods. Journal of Food Composition and Analysis, 59, 95-104. [CrossRef]

9. Şöhretoğlu, D., Sakar, M. K. (2004). Polyphenolic constituents and biological activities of Quercus species. Journal of Faculty of Pharmacy of Ankara University, 33(3), 183-215. [CrossRef]

10. Vivas, N., Nonier, M. F., de Gaulejac, N. V., de Boissel, I. P. (2004). Occurrence and partial characterization of polymeric ellagitannins in Quercus petraea Liebl. and Q. robur L. wood. Comptes Rendus Chimie, 7(8-9), 945-954. [CrossRef] 
11. Bulut, G., Haznedaroğlu, M. Z., Doğan, A., Koyu, H., Tuzlac1, E. (2017). An ethnobotanical study of medicinal plants in Acipayam (Denizli-Turkey). Journal of Herbal Medicine, 10, 64-81. [CrossRef]

12. Cakilcioglu, U., Turkoglu, I. (2010). An ethnobotanical survey of medicinal plants in Sivrice (Elazığ-Turkey). Journal of Ethnopharmacology, 132(1), 165-175. [CrossRef]

13. Senkardes, I., Tuzlaci, E. (2014). Some Ethnobotanical Notes from Gundogmus District (Antalya/Turkey). Clinical and Experimental Health Sciences, 4(2), 63.

14. Sargin, S. A. (2021). Plants used against obesity in Turkish folk medicine: A review. Journal of Ethnopharmacology, 113841. [CrossRef]

15. Sargın, S. A., Akçicek, E., Selvi, S. (2013). An ethnobotanical study of medicinal plants used by the local people of Alaşehir (Manisa) in Turkey. Journal of Ethnopharmacology, 150(3), 860874. [CrossRef]

16. Sargin, S. A., Selvi, S., Büyükcengiz, M. (2015). Ethnomedicinal plants of Aydinc1k district of Mersin, Turkey. Journal of Ethnopharmacology, 174, 200-216. [CrossRef]

17. Polat, R., Cakilcioglu, U., Sat1l, F. (2013). Traditional uses of medicinal plants in Solhan (Bingö1Turkey). Journal of Ethnopharmacology, 148(3), 951-963. [CrossRef]

18. Kültür, Ş. (2007). Medicinal plants used in Kurklareli province (Turkey). Journal of Ethnopharmacology, 111(2), 341-364. [CrossRef]

19. Sezik, E., Yeşilada, E., Honda, G., Takaishi, Y., Takeda, Y., Tanaka, T. (2001). Traditional medicine in Turkey X. Folk medicine in central Anatolia. Journal of Ethnopharmacology, 75(23), 95-115. [CrossRef]

20. Carrió, E., Vallès, J. (2012). Ethnobotany of medicinal plants used in eastern Mallorca (Balearic Islands, Mediterranean Sea). Journal of Ethnopharmacology, 141(3), 1021-1040. [CrossRef]

21. Gilca, M., Tiplica, G. S., Salavastru, C. M. (2018). Traditional and ethnobotanical dermatology practices in Romania and other Eastern European countries. Clinics in Dermatology, 36(3), 338352. [CrossRef]

22. Leporatti, M. L., Ivancheva, S. (2003). Preliminary comparative analysis of medicinal plants used in the traditional medicine of Bulgaria and Italy. Journal of Ethnopharmacology, 87(2-3), 123142. [CrossRef]

23. Sõukand, R., Pieroni, A. (2016). The importance of a border: medical, veterinary, and wild food ethnobotany of the Hutsuls living on the Romanian and Ukrainian sides of Bukovina. Journal of Ethnopharmacology, 185, 17-40. [CrossRef]

24. Šrarić-Kundalić, B., Dobeš, C., Klatte-Asselmeyer, V., Saukel, J. (2010). Ethnobotanical study on medicinal use of wild and cultivated plants in middle, south and west Bosnia and Herzegovina. Journal of Ethnopharmacology, 131(1), 33-55. [CrossRef] 
25. Alkofahi, A., Atta, A. H. (1999). Pharmacological screening of the anti-ulcerogenic effects of some Jordanian medicinal plants in rats. Journal of Ethnopharmacology, 67(3), 341-345. [CrossRef]

26. Andrenšek, S., Simonovska, B., Vovk, I., Fyhrquist, P., Vuorela, H., Vuorela, P. (2004). Antimicrobial and antioxidative enrichment of oak (Quercus robur) bark by rotation planar extraction using ExtraChrom ${ }^{\circledR}$. International Journal of Food Microbiology, 92(2), 181-187. [CrossRef]

27. Berahou, A., Auhmani, A., Fdil, N., Benharref, A., Jana, M., Gadhi, C. A. (2007). Antibacterial activity of Quercus ilex bark's extracts. Journal of Ethnopharmacology, 112(3), 426-429. [CrossRef]

28. Deryabin, D. G., Tolmacheva, A. A. (2015). Antibacterial and anti-quorum sensing molecular composition derived from Quercus cortex (Oak bark) extract. Molecules, 20(9), 17093-17108. [CrossRef]

29. Frédérich, M., Marcowycz, A., Cieckiewicz, E., Mégalizzi, V., Angenot, L., Kiss, R. (2009). In vitro anticancer potential of tree extracts from the Walloon Region forest. Planta medica, 75(15), 1634-1637. [CrossRef]

30. Gharzouli, K., Khennouf, S., Amira, S., Gharzouli, A. (1999). Effects of aqueous extracts from Quercus ilex L. root bark, Punica granatum L. fruit peel and Artemisia herba- alba Asso leaves on ethanol- induced gastric damage in rats. Phytotherapy Research: An International Journal Devoted to Pharmacological and Toxicological Evaluation of Natural Product Derivatives, 13(1), 42-45. [CrossRef]

31. Güllüce, M., Adıgüzel, A., Öğütçü, H., Şengül, M., Karaman, I., Şahin, F. (2004). Antimicrobial effects of Quercus ilex L. extract. Phytotherapy Research: An International Journal Devoted to Pharmacological and Toxicological Evaluation of Natural Product Derivatives, 18(3), 208-211. [CrossRef]

32. Jassim, S. A. A., Naji, M. A. (2003). Novel antiviral agents: a medicinal plant perspective. Journal of Applied Microbiology, 95(3), 412-427. [CrossRef]

33. Khennouf, S., Benabdallah, H., Gharzouli, K., Amira, S., Ito, H., Kim, T. H., Yoshida, T., Gharzouli, A. (2003). Effect of tannins from Quercus suber and Quercus coccifera leaves on ethanol-induced gastric lesions in mice. Journal of Agricultural and Food Chemistry, 51(5), 1469-1473. [CrossRef]

34. Panchal, S. K., Brown, L. (2013). Cardioprotective and hepatoprotective effects of ellagitannins from European oak bark (Quercus petraea L.) extract in rats. European Journal of Nutrition, 52(1), 397-408. [CrossRef]

35. Davis, P. H. (1982). Flora of Turkey and the East Aegean Islands. Edinburgh, UK: Edinburgh University Press.

36. Güner, A., Aslan, S., Ekim, T., Vural, M., Babaç, M. T. (2012). Türkiye Bitkileri Listesi (Damarlı Bitkiler). Nezahat Gökyigit Botanik Bahçesi Yayınları, Flora Dizisi I. 
37. EUCAST. (2021). European Committee on Antimicrobial Susceptibility Testing. https://www.eucast.org/fileadmin/src/media/PDFs/EUCAST_files/Breakpoint_tables/v_11.0_Br eakpoint_Tables.pdf Accessed: 19.11.2021.

38. Villas- Bôas, S. G., Mas, S., Åkesson, M., Smedsgaard, J., Nielsen, J. (2005). Mass spectrometry in metabolome analysis. Mass spectrometry reviews, 24, 613-646. [CrossRef]

39. Blau, K., Halket, J. M. (1993). Handbook of derivatives for chromatography. Wiley.

40. Şöhretoğlu, D., Ekizoglu, M., Kiliç, E., Sakar, M. K. (2007). Antibacterial and antifungal activities of some Quercus species growing in Turkey. FABAD Journal of Pharmaceutical sciences, 32(3), 127.

41. Ahmed, M., Adil, M., Haq, I., Tipu, M. K., Qasim, M., Gul, B. (2021). RP-HPLC-based phytochemical analysis and diverse pharmacological evaluation of Quercus floribunda Lindl. ex A. camus nuts extracts. Natural Product Research, 35(13), 2257-2262. [CrossRef]

42. Aleebrahim-Dehkordy, E., Rafieian-kopaei, M., Amini-Khoei, H., Abbasi, S. (2019). In vitro evaluation of antioxidant activity and antibacterial effects and measurement of total phenolic and flavonoid contents of Quercus brantii L. fruit extract. Journal of Dietary Supplements, 16(4), 408-416. [CrossRef]

43. Elansary, H. O., Szopa, A., Kubica, P., Ekiert, H., Mattar, M. A., Al-Yafrasi, M. A., El-Ansary, D. O., Zin Elabadin, T. K., Yessoufou, K. (2019). Polyphenol profile and pharmaceutical potential of Quercus spp. bark extracts. Plants, 8(11), 486. [CrossRef]

44. Dettweiler, M., Lyles, J., Nelson, K., Dale, B., Reddinger, R., Zurawski, D., Quave, C. L. (2019). American civil war plant medicines inhibit growth, biofilm formation, and quorum sensing by multidrug-resistant bacteria. Scientific Reports, 9, 7692. [CrossRef]

45. Sánchez-Burgos, J. A., Ramírez-Mares, M. V., Larrosa, M. M., Gallegos-Infante, J. A., GonzálezLaredo, R. F., Medina-Torres, L., Rocha-Guzmán, N. E. (2013). Antioxidant, antimicrobial, antitopoisomerase and gastroprotective effect of herbal infusions from four Quercus species. Industrial Crops and Products, 42, 57-62. [CrossRef] 